\title{
The Borderline Between Legitimate and Unfair Copying of Products - A Unified Scandinavian Approach?
}

\author{
Monica Viken
}

Published online: 10 November 2020

(C) The Author(s) 2020

\begin{abstract}
Freedom of imitation, outside the boundaries of intellectual property protection, can be considered as a prerequisite for free competition in a free market economy. The rules on unfair competition should therefore not serve to extend exclusive rights beyond their scope and term of protection. On the other hand, regulations within national law that prohibit the unfair copying of products may be justified in order to avoid market failure, being directed towards the optimizing of fair competition among honest traders. The borderline between these two opposite positions is regulated with different approaches in the European countries. This article considers the extent to which the public interest in free competition and the protection of a trader against unfair competition function together in a complementary manner under Scandinavian legislation. In the early 1970s, the Scandinavian countries developed a distinctive approach to regulations on unfair competition under the Marketing Laws. This article undertakes an investigation of these regulations relating to the borderline between legitimate and unfair copying as of 2020, revealing the extent to which there is a unified approach to copying in Scandinavia. Differences between the regulations will have influence on the legal relationship and conflicts among traders operating in all three countries, while a unified Scandinavian approach could serve as a robust solution for navigating the borderline between legitimate and unfair copying. Such analysis might also shed light on how a Scandinavian approach fits into a broader European perspective on this borderline. Thus, the aim of this article is to analyze potential different approaches to the tension between the marketing rules outside the boundaries of intellectual property protection and the principle of legitimate copying. Examination of this borderline can be connected to how the trader's investments and behaviour are balanced against a market-oriented approach to copying.
\end{abstract}

\footnotetext{
M. Viken $(\bowtie)$

Professor of Law, Department of Law and Governance, BI Norwegian Business School, Oslo, Norway

e-mail: monica.viken@bi.no
} 
Keywords Copying of products - Imitations - Marketing law · Unfair competition · Intellectual property $\cdot$ Scandinavia

\section{Introduction and Legal Context}

Our cultural and technological development are to a great extent founded on legitimate copying, being part of a free market economy and a principle of free competition. Interventions in these market forces require specific justifications; thus, the Paris Convention states that even though competition should be free, exclusive rights in the field of intellectual property are accepted. ${ }^{1}$ Rules on intellectual property are weighed, on the one hand, as general assessments of the public interest in free competition against, on the other hand, innovation and traders' income. ${ }^{2}$ Securing the interests of honest traders, nations are bound to assure effective protection against unfair competition (Paris Convention Art. 10 $0^{\text {bis }}$ ).

As a principle, it is agreed that rules on unfair competition should not serve to extend exclusive intellectual property rights beyond their scope and term of protection. Nevertheless, both the creation of incentives by means of exclusive rights, as well as selective intervention to avoid a market failure, are directed towards optimizing competition. ${ }^{3}$

The topic discussed in this article concerns the extent to which the public interest in free competition and the protection of a trader against unfair competition function together in a complementary manner in national legislation, striking a fair balance in business society. ${ }^{4}$ In specific terms, this article will investigate Scandinavian regulations on the borderline between legitimate and unfair copying outside the scope of intellectual property rights. ${ }^{5}$ Lessons learned from the Scandinavian countries might be fruitful as an input in a broader European perspective on this topic, and even function as a backdrop for considering harmonization within the EU.

Contrary to intellectual property rights, regulations on unfair competition are not harmonized in the EU; thus, specific national regulations on unfair copying of products are part of a system running alongside the EU system. ${ }^{6}$ The Court of Justice of the European Union (CJEU) has stated that even though national

\footnotetext{
${ }^{1}$ Paris Convention for the Protection of Industrial Property of 20 March 1883, as revised at Brussels on 14 December 1900, at Washington on 2 June 1911, at The Hague on 6 November 1925, at London on 2 June 1934, at Lisbon on 31 October 1958, and at Stockholm on 14 July 1967, and as amended on 28 September 1979.

2 Llewelyn and Aplin (2019), No. 1-040; and Ohly (2010), p. 510.

${ }^{3}$ Hilty and Henning-Bodewig (eds.) (2007), p. 3.

${ }^{4}$ Ohly (2010), p. 510.

5 I have not found a comparative analysis of Scandinavian legislation in European legal theory, but copying of products is discussed from different angles, see for example Knoph (1936), pp. 543-548; Koktvedgaard (1965), p. 328 ff.; Levin (1984), p. 122; Lunde (2001), p. 214 ff.; Borcher (2003); Engelbrekt (2007), pp. 161-181; Kur (2009), pp. 521-533; Ohly (2010), pp. 506-524; Schovsbo (2011), pp. 165-180; Stenvik (2013), p. 15; Levin (2017), pp. 283-300; Heide-Jørgensen (2017), pp. 389-391; Nordell (2017), pp. 221-232; and Rognstad (2019), p. $67 \mathrm{ff}$.

6 The CJEU in C-267-268/91 (Keck), para. 16. See Rognstad (2000), pp. 326-327; and Bernitz et al. (2017), p. 357.
} 
protection against slavish imitation is an obstacle to the free movements of goods, it was justified by the mandatory requirements of fairness in commercial transactions. ${ }^{7}$ The CJEU has also commented that outside the scope of intellectual property a three-dimensional sign, where appropriate, can be examined in light of the rules on unfair competition. ${ }^{8}$ As for design, Design Regulation Art. 96 states that the provisions shall be without prejudice to any national provisions relating to unfair competition. ${ }^{9}$ Since unfair competition is not regulated by the TRIPS Agreement, there are few international restraints on national provisions on the copying of products. ${ }^{10}$ Thus, misappropriation of commercially valuable achievements as a form of unfair business practice is typically subject only to national law and jurisprudence. $^{11}$

EU directives in other areas, which may influence national legislation on the copying of products, are the Misleading and Comparative Advertising Directive (MCA Directive) $^{12}$ and the Unfair Commercial Practice Directive (UCP Directive). ${ }^{13}$ Both the MCA Directive and the UCP Directive are tools for ensuring the proper functioning of the market, facilitating fair marketing and competition. ${ }^{14}$ In addition, the Trade Secret Directive, on the protection of undisclosed know-how and business information against their unlawful acquisition, will have an impact on regulations relating to the copying of products. ${ }^{15}$ Developed soft law, e.g. guidelines in the ICC Advertising and Marketing Communications Code (ICC code), might also be taken into account when considering the copying of products among traders. $^{16}$

Due to historical, geographical, cultural, linguistic and legal similarities, I have chosen to investigate regulations on the copying of products in Scandinavia. While Denmark and Sweden are EU members, Norway is not. Nevertheless, Norway participates indirectly through the EEA agreement and is bound by Community law

\footnotetext{
${ }^{7}$ Case 6/81 (BV Industrie Diensten Groep v. J.A. Beele Handelsmaatschappij). See Henning-Bodewig (2006), p. 29; and Kur (2009), pp. 530-531.

${ }^{8}$ See the trademark case C-48/09 P (Lego), para. 61. See also C-252/08 (Intel Corporation), para. 24 ff.; and C-487/07 (L'Oréal and others), para. $37 \mathrm{ff}$.

${ }^{9}$ Council Regulation (EC) No. 6/2002 of 12 December 2001 on Community designs. See also Directive 98/71/EC of the European Parliament and of the Council of 13 October 1998 on the legal protection of designs.

${ }^{10}$ Agreement on Trade-Related Aspects of Intellectual Property Rights (TRIPS), Marrakesh, Morocco on 15 April 1994. Annex 1C to the Agreement Establishing the World Trade Organisation of 15 April 1994.

${ }^{11}$ Kur (2009), p. 522.

12 Directive 2006/114/EC of the European Parliament and of the Council of 12 December 2006 concerning misleading and comparative advertising (codified version).

${ }^{13}$ Directive 2005/29/EC of the European Parliament and of the Council of 11 May 2005 concerning unfair business-to-consumer commercial practices in the internal market.

${ }^{14}$ The MCA Directive and UCP Directive are based on TFEU Art. 114 aimed to achieve the objectives set out in Art. 26. See Madsen (2017), p. 179.

${ }^{15}$ Directive 2016/943/EC on the protection of undisclosed know-how and business information against their unlawful acquisition.

${ }^{16}$ International Chambers of Commerce Consolidated Code of Advertising and Marketing Communications Practice (2018 edn.), https://cms.iccwbo.org/content/uploads/sites/3/(2018/09/icc-advertisingand-marketing-communications-code-int.pdf. See Trzaskowski (2017), pp. 93-94.
} 
and CJEU rulings. ${ }^{17}$ Thus, harmonized EU directives will be implemented in all three countries.

The Scandinavian countries, together with Finland, developed a distinctive approach to regulations on unfair competition in the early 1970s, emphasizing not only competitors' interests, but also consumers' collective interests and the interests of society. ${ }^{18}$ The Scandinavian consumer-orientated approach was enacted by the Marketing Laws and served as an alternative to the dominant competition-oriented approach. ${ }^{19}$ Regulations on unfair commercial copying and imitation should prevent traders from engaging in anti-competitive practices and provide consumer protection. The UCP Directive seems to be influenced by Scandinavian law and practice. $^{20}$ Thus, in the wake of these Scandinavian laws, several legal considerations are emerging in a way that should attract attention in EU and EEA Member States.

In light of the coordinated legislation affirmed in the 1970s and the well-known similarities within the Scandinavian countries, one would assume a similar approach to copying across Norway, Sweden and Denmark, as of 2020. Comparative analysis will reveal to what extent there is a unified Scandinavian approach towards the copying of products or whether there are differentiated assessments of what is a fair balance between the public interest in free competition and the protection of a trader against unfair competition. Differences between the regulations will have influence on the legal relationship and conflicts among traders operating in all three countries, while a unified Scandinavian approach could serve as a robust solution for navigating the borderline between legitimate and unfair copying. Such analysis might also shed light on how a Scandinavian approach fits into a broader European perspective on this borderline. Thus, the aim of this article is to analyze potential different approaches to the tension between the marketing rules outside the boundaries of intellectual property protection and the principle of legitimate copying.

\section{Regulations on Copying of Products in Scandinavia}

\subsection{Norway}

Regulations on the protection of the interests of traders are placed under the Norwegian Marketing Control Act (MCA) ch. $6 .^{21}$ The unfair copying of products

\footnotetext{
17 Agreement on the European Economic Area, Art 3. See Sejersted et al. (2011), p. 195 ff.

18 See preparatory works: Innst til konkurranselovkomiteen 1966 (Norway); Betænkning 416/1966 angående ny Konkurrencelov (Denmark); SOU 1966:71 Otilbörlig konkurrens (Sweden); and KM 1967:A9 (Finland). See Engelbrekt (2007), pp. 162 and 165. With Scandinavia as my focus, I have not included Finland in my studies, even though it participated in the original common approach.

19 Engelbrekt (2007), p. 161.

${ }^{20}$ Directive 2005/29/EC of the European Parliament and of the Council of 11 May 2005 concerning unfair business-to-consumer commercial practices in the internal market. See Engelbrekt (2007), p. 161.

21 Act relating to the control of marketing and contract terms and criteria 9 January 2009 No. 2. See preparatory works, Ot.prp. No. 57 (1971-72), p. 27, and Ot.prp. No. 55 (2007-2008), p. 9.
} 
was interpreted as a breach of the general clause in the Unfair Competition Act of 1922. ${ }^{22}$ A rich body of case law connected to the copying of products was developed under the general clause, and the government enacted specific regulations under the Marketing Control Act of 1972, continued in the Act of $2009 .^{23}$ Prohibition of unfair copying of products is today regulated by MCA $\S 30$ :

$\S 30$. Copying the products of another person

It shall be prohibited in the course of trade to use copies of distinguishing marks, products, catalogues, advertising materials or other produced items in such a manner and under such circumstances that the use must be considered an unfair exploitation of the efforts or results of another person, and to present a risk of confusion.

Prohibition of unfair copying of products may also be based on the general clause MCA $\S 25$ :

\section{$\S 25$. Good business practice}

No act shall be performed in the course of trade which conflicts with good business practice among traders.

The relationship between MCA $\S 30$ and $\S 25$ raises several questions which will be discussed further in this article. Both regulations take consumer protection under Norwegian legislation into account to some degree. ${ }^{24}$

There are no specialized courts judging marketing law or intellectual property law in Norway, but the Oslo District Court operates as an exclusive legal venue for infringement cases based on intellectual property laws. ${ }^{25}$ There are few Supreme Court decisions, but several from the courts of appeal and the district courts, dealing with cases on copying. In addition, an alleged breach of MCA ch. 6 can be considered by a Council dealing with Unfair Marketing Practices (NKU), whose statements are not legally binding, but might still be seen as accepted practice among traders. ${ }^{26}$

In order to gain protection based on MCA $\S 30$, the trader must prove that the alleged infringing product is a copy, that use of it is an unfair exploitation of one's effort or result, presenting a risk of confusion between the original product and the copy. The criteria are cumulative and must all be fulfilled in order to qualify for prohibition of unfair copying. MCA $\S 30$ regulates the unfair copying of distinguishing marks, products, catalogues, advertising materials or other produced items. Thus, there are few limitations on what object can be protected. ${ }^{27}$ Even

\footnotetext{
22 Brunsvig (1960), p. $146 f f$.

23 Preparatory works, Innst. fra Konkurranselovkomitéen 1966, p. 36, and Ot.prp. No. 57 (1971-72), p. 27.

24 Lunde (2001), p. 275. The Supreme Court Rt 1994, p. 1584.

25 Discussed when implementing Directive 2004/48/EC of the European Parliament and of the Council of 29 April 2004 on the enforcement of intellectual property rights, see Prop. 81 L (2012-2013), p. 85; and for copyright, Prop 104 L (2016-2017), p. 294. In addition, decisions from the Industrial Property Office may be appealed to the Norwegian Board of Appeal for Industrial Property Rights (KFIR).

26 Homepage, http://konkurranseutvalget.no/konkurranseutvalget-forsiden/.

27 The Court of Appeal LB-2007-135832 and LB-2009-178954. See also Stenvik (2002), p. 482 ff.
} 
products no longer produced by the original manufacturer can still be protected, if they have a secondhand market among consumers. ${ }^{28}$

The criterion of being a copy is fundamental, and supports the fact that the original manufacturer must first prove the existence of an existing original product, in order to claim that there is an unfair copy. The point is illustrated by a case before the Court of Appeal, where it was pleaded that a roller coaster was an unfair copy of a film car. ${ }^{29}$ The court stated that the roller coaster had its origin in drawings by a famous author and not in the film car; thus, similarities between the products could be explained by the fact that they were both based on the same original drawings. Therefore, the court concluded that it was not a case of copying. Furthermore, if the newcomer's product is based on an independent effort, it is not considered illicit copying. ${ }^{30}$ The criterion of copying is interpreted further, in the sense that it is not possible to assert protection if the new product was created without knowledge of an existing one. ${ }^{31}$ Consequently, only intentional copying can be prohibited, based on MCA $\S 30$. The Court of Appeal has, in several cases, made presumptions about intentional copying, because it was not possible that the new product, due to its similarities to the original, could have been developed without knowledge of the existing one. ${ }^{32}$

Secondly, it is a criterion for breach of $\S 30$ that there is is an unfair exploitation of the effort or results of another person. In addition to the requirement of disloyal behaviour linked to unfair competition, there is a requirement for proving effort or result on the part of the original manufacturer, in order to be protectable.

The original manufacturer must prove a certain level of independent work or investments in time and resources, capital input and marketing costs, in order to gain protection. Consequently, if the original manufacturer cannot prove a protectable effort, it is not a case of illegal copying. The Supreme Court, assessing copying of the original Lego toy bricks, stated that the Lego company had extracted its earnings potential in the market and had covered the costs related to developing the Lego bricks. ${ }^{33}$ According to the Court, Lego had been paid for its efforts after several years of marketing and there was no current need for further protection.

Closely related to invested effort, a protectable result may provide a ground for the prohibition of copying. As an example, obtained goodwill and market value can be protectable. ${ }^{34}$ When assessing protectable results, important elements can be market share, marketing costs and market position, based on successful marketing

\footnotetext{
28 The Court of Appeal LA-2019-128467.

${ }^{29}$ The Court of Appeal LE-2017-187139. Nor was the roller coaster an infringement of copyright, see the Supreme Court HR-2017-2165-A.

30 The Court of Appeal LB-2018-142457, p. 14.

31 The Court of Appeal RG 2013, p. 961 and LB-2018-142457. For a comparison with copyright rules, see Rognstad (2019), pp. 162-163.

32 The Court of Appeal LB-2000-3388, LB-2010-118311 and RG 2013, p. 961.

33 The Supreme Court Rt 1994, p. 1584. See also the Court of Appeal LB-2006-3616 and RG 1998, p. 277.

${ }^{34}$ Innst. fra Konkurranselovkomitéen 1966, p. 36, and Ot.prp. No. 57 (1971-1972), p. 28. See Lunde and Michaelsen (2019), p. 356.
} 
campaigns and marketing activity. ${ }^{35}$ The Supreme Court has not established a clear criterion for the original product to be distinctive, but a product's distinctiveness can be included as one of several elements in a comprehensive and dynamic interpretation of $\S 30 .^{36}$ As an exception, extensive case law has interpreted that there is no protection for products consisting solely of technical solutions. ${ }^{37}$

Unfair behaviour relates to the criterion for unfair exploitation of efforts or result, in relation to the specific exploitation of goodwill and market position. ${ }^{38}$ An overall assessment of unfair exploitation will take into account the uniqueness of the original product, market position, product development or goodwill, weighed against how deliberate or systematic the copying is, the product's time on the market, or the unfair advantage of earlier connections between the traders. ${ }^{39}$ Furthermore, slavish imitation is stated as being unfair, and when developing new products, traders have a duty to do whatever it takes to vary the design, making sure that the product differs from the original, in order to avoid prohibition. ${ }^{40}$ The extent to which it is a prerequisite for proved subjective infringement (culpability) to demonstrate disloyal behaviour is disputable, but the newcomer's conduct in each case will be a part of an overall assessment, due to the wording in such a manner and under such circumstances. ${ }^{41}$

The third criterion in the Norwegian MCA $\S 30$ is that there must be a risk of confusion between the original product and the alleged infringing product, in order to impose prohibition. The overall perception in the relevant sector of the public, by both existing and potential customers, is decisive. ${ }^{42}$ Risk of confusion may arise if customers are likely to buy the copy product, believing they bought the original, or if they associate the copy product with the manufacturer of the original one. ${ }^{43}$ If an overall impression of the newcomer's product gives a very different impression compared to the original product, there is no risk of confusion. ${ }^{44}$ On the other hand, minor adjustments in details, which alter the impression, may not be enough to

\footnotetext{
35 The Supreme Court Rt 2005, p. 1560. See Knoph (1936), p. 559; Brunsvig (1960), p. 157 ff.; Lunde (2001), p. 262; and Løchen and Grimstad (2003), p. 157.

${ }^{36}$ Lunde and Michaelsen (2019), p. 358. See also Lunde (2001), p. 258; and Helset et al. (2009), p. 569.

37 Innst. fra Konkurranselovkomiteen 1966, p. 24, the Supreme Court Rt 1994, p. 1584, the Court of Appeal LB-2003-1979, LB-2006-3616, LG-2016-44586, and the District Court TOSLO-2017-75998.

38 See for example the Court of Appeal LB-2006-3616 and LB-2007-95820.

39 The Supreme Court Rt 1959, p. 712, Rt 2000, p. 1698, Rt 2010, p. 110, and several decisions of the Court of Appeal. See Lunde and Michaelsen (2019), p. 364.

40 The Supreme Court Rt 2005, p. 1560, and several decisions of the Court of Appeal and NKU. See Løchen and Grimstad (2003), p. 158; and Helset et al. (2009), p. 603 ff.

${ }^{41}$ Culpability was not required in the Supreme Court Rt 1997, p. 199, and Rt 1998, p. 1315, while the Court seems to put more emphasis on subjective elements in Rt 1994, p. 1584, and Rt 1995, p. 1908. See Lunde (2001), pp. 210, 246, 268 ff.; Helset et al. (2009), pp. 563-565; Wold (2010), p. 140; Lunde and Michaelsen (2019), pp. 356, 363-364; and Rognstad (2019), pp. 163-164.

42 The Court of Appeal in LF-2000-1115, RG 2002, p. 1060, LG 2007-160205, LF-2009-117966, LA2010-35846 and LB-2015-134806. See also NKU 2005-10.

43 The Court of Appeal RG 1997, p. 258. See Lunde (2001), p. 235.

44 The Supreme Court Rt. 1985, p. 612, and Rt 2000, p. 1698. LF-2005-120379. See NKU-2015-11, NKU-2018-8. See Knoph (1936), p. 563; Lunde (2001), p. 234 ff.; Løchen and Grimstad (2003), p. 163; Lunde and Michaelsen (2019), p. 366.
} 
avoid a risk of confusion. The Court of Appeal has stated in a case of alleged copying of jewelry that even though it was possible to point out differences between the two products, it was not normal behaviour for a consumer to look for minor differences, and the court stated there was a risk of confusion. ${ }^{45}$ If the product name and/or the packaging of the alleged offending product is very different from the original, the courts have stated there is no risk of confusion. ${ }^{46}$

The buying situation is also important in the assessment of a risk of confusion. ${ }^{47}$ When interpreting the consumer's perception, some court decicisons have pointed out that tourists, for instance, as the relevant sector of the public, usually buy souvenirs in a hurry and on impulse, and they will be easily confused. ${ }^{48}$ The courts have also stressed the importance of presumed knowledge of the product at hand, stating that a professional customer with a high level of knowledge reduces the risk of confusion compared to a consumer with low awareness. ${ }^{49}$ It is stated that consumers would not confuse a pair of sneakers meant for the high-end market with a cheaper pair meant for the lower end of the market. ${ }^{50}$

Norwegian sources reveal that a risk of confusion is not required for a majority of the relevant public. If a not insignificant part of the relevant public assumes that there is some kind of relationship between the products, it amounts to a risk of confusion. $^{51}$

One topic for discussion is the extent to which the copying of products can be assessed as a question of a breach of good business practice under the general clause in MCA $\S 25$, as a supplement to the specific rule in MCA $\S 30 .{ }^{52}$ Some sources state that the general clause should not be used if all elements of the specific rule are considered and found not to be fulfilled. ${ }^{53}$ Nevertheless, the general clause has been considered as a supplement when the criteria in $\S 30$ are not fulfilled, e.g. a risk of confusion is not proved. ${ }^{54}$ It is also pointed out that if specific circumstances exist as elements outside the scope of MCA $\S 30$, e.g. previous connections between the traders, these may be part of the assessment of unfair business practice in MCA $\S 25 .{ }^{55}$ Case law is inconsistent concerning the general clause as a supplement to the

\footnotetext{
45 The Court of Appeal LA-2010-35846.

46 The Supreme Court Rt 1985, p. 612, and Rt 1994, p. 1584, and Court of Appeal RG 1998, p. 277, RG 2005, p. 991, LB-2006-3616 and LB-2017-128626. See also NKU 1996-7/8 NKU 2018-6.

47 The Supreme Court Rt. 2005, p. 1560. See Lunde (2001), p. 242; and Helset et al. (2009), p. 600.

48 The Court of Appeal LF-2000-1115 and RG 2002, p. 1060.

49 The Supreme Court Rt 1962, p. 964 (based on the general clause), and Rt 2000, p. 1698. The same is stated in a number of decisions in the Court of Appeal and NKU.

50 The Court of Appeal RG 1986, p. 1010. In the same direction, District Court TOSLO-2009-188723.

51 The Supreme Court Rt 1999, p. 641, concerning trademark law. See also the Court of Appeal RG 1997, p. 258. See Lunde (2001), p. 238; and Helset et al. (2009), p. 582.

52 Lunde (2001), p. 230 ff.; Helset et al. (2009), p. 626 ff.; and Ringnes (2016), p. 759.

53 Preparatory works, Innstilling fra Konkurranselovkomiteen 1966, pp. 23-24, and Ot.prp. No. 57 (1971-72), p. 27. See the Supreme Court Rt 1995, p. 1908, and Rt 1998, p. 1315, and several decisions of the Court of Appeal.

54 The Supreme Court Rt 1994, p. 1584, Rt 1995, p. 1908, and Rt 1998, p. 1315, and a number of decisions of the Court of Appeal and NKU. See also Løchen and Grimstad (2003), p. 165.

55 The Supreme Court Rt 1959, p. 712, Rt. 1997, p. 199, and Rt 2000, p. 110.
} 
specific rule on copying. ${ }^{56}$ In general, the original manufacturer will plead both provisions to provide for a safety net.

Unfair copying of products may also be a question of misleading or comparative advertising, based on the MCA Directive and a specific regulation in Norwegian legislation. ${ }^{57}$ The importance of rules on unfair copying seems to be further extended in a new act on good trading practice in the retail industry, comprising a specific regulation on unfair copying, concurrent with MCA $\S 30 .^{58}$

Norwegian legislation seems to put great weight on protecting traders' investments against disloyal behaviour by competitors.

\subsection{Sweden}

Implementation of the Paris Convention Art. $10^{\text {bis }}$ No. 3 was developed under Swedish case law, with landmark decisions from the Market Court (MD), which were rather restrictive in applying the existing general clause to situations outside the scope of intellectual property protection. ${ }^{59}$ A codification of the developed case law on the misleading copying of products was first introduced into statutory law in 1995, then continued in the Marketing Act (MA) of 2008. ${ }^{60}$ The specific provision regulating the copying of products is today enacted in $\S 14$ MA:

\section{$\S 14$ Misleading copies}

A trader may not, in the course of marketing, use copies that are misleading in that they can easily be confused with another trader's known and distinctive products. This does not, however, apply to copies the design of which is primarily intended to render the product functional.

The specific provision of $\S 14$ MA is positioned among other rules on misleading marketing, concerning both consumers and business society. The provision overlaps with $\S 10 \mathrm{MA}$, implementing the UCP Directive and prohibiting any representation that is misleading with respect to the trader's own or another person's business activity, where it concerns, for instance, a product's origin, trademarks or other rights of the trader. ${ }^{61}$ In addition, the general clause in $\$ 5$ MA will often be pleaded in a case of copying, stating that "[m]arketing shall be consistent with good marketing practice", typically where it concerns free riding on another's market reputation. ${ }^{62}$

\footnotetext{
56 In some court decisions there seems to be a mix of both, or else it is unclear as to whether they are based on MCA $\S 30$ or $\S 25$.

57 Norwegian regulation on comparative advertising 19 December 2000, No. 1653, see $\S 3$.

58 Act relating to good trading practice 17 April 2020, No. 29. The new act is aimed at preventing traders from developing business strategies intended to take advantage of a dual position, both as a customer and as a competitor, see Prop. 33 L 2019-2020, p. 67.

59 Engelbrekt (2007), p. 169; and Henning-Bodewig (ed.) (2013), p. 513 ff.

60 SFS 2008:486 Marketing Act, see Prop. 2007/08:115, p. 102, replacing SFS 1995:450 Marketing Act, see Prop. 1994/95:123, p. 57.

61 Preparatory works, Prop. 2007/08:115, p. 148 ff., and SOU 2006:76, p. 240. See Bernitz et al. (2017), pp. 358-359. MD 2016:7, para. 23, MD 2013:3. As for the sanctions, it makes no difference whether prohibition of misleading copying is based on $\S 10$ or $\S 14$, see Levin (2017), p. 285.

62 Bernitz et al. (2017), p. 354.
} 
Extensive case law concerning misleading copying based on marketing rules was found in the Market Court, until it was replaced by the Patent and Market Court of Appeal (with the Patent and Market Court as first instance) from 1 September $2016 .^{63}$

There are three cumulative criteria for prohibiting misleading copying, based on $\S 14$ MA: the product must be known, distinctive, and the alleged infringing product must be capable of being easily confused with the original. It is explicitly stated that functional elements should not be protected. Furthermore, § 8 MA applies when assessing the copying of products, stating that marketing that is misleading is to be regarded as unfair only if it "affects or probably affects the recipient's ability to make a well-founded transaction decision”.

The wording in $\S 14$ relates only to products, but this is interpreted as meaning protection for not only the product itself, its packaging, service and marketing in a broad sense, but also that even concepts can be protected. ${ }^{64}$

To gain protection, the original product must have a mainly distinctive function, which in an aesthetic manner separates it from other products in the market. ${ }^{65}$ When enacting the specific rule in $\S 14 \mathrm{MA}$, it was assumed that the criterion for protection of products from copying, stated in the wording "known" and "distinctive", would be assessed in the same way as in former case law. ${ }^{66}$ The need for protection arises when the commercial distinctive shape of the product, or its packaging, give consumers the clearest signal of its quality or origin. ${ }^{67}$ It is also possible to gain distinctiveness through extensive use, as in trademark law, and, by doing so, the criterion for being known will also be fulfilled. ${ }^{68}$ Elements primarily intended to render the product functional cannot gain distinctiveness. ${ }^{69}$

Misleading copying can only come into question if the original product is known in such a way that the original product is associated with one specific company in the relevant sector of the public. ${ }^{70}$ The Patent and Market Court of Appeal seem to set the same requirements in their assessments as the Market Court, considering perception by the relevant sector of the public as being in line with the average consumer, as defined by the CJEU. ${ }^{71}$ Interpretation of whether the product is both distinctive and known is influenced by trademark cases before the CJEU, which regard perception as being that of a considerable amount of the relevant sector of the

\footnotetext{
${ }^{63}$ SFS 2016:188 Act on Patent and Market Courts, see preparatory works, Prop. 2015/16:57.

64 MD 1992:26 and MD 2012:10.

65 Prop. 2007/08:115, p. 102. See MD 2009:12, MD 2010:4, MD 2010:27, MD 2010:29 and MD 2016:11, and the Patent and Market Court of Appeal PMT 5365-17.

66 Prop. 1994/95:123, pp. 59 and 168.

67 SOU 1993:59, p. 3.

68 See for example MD 2013:11, para. 106.

69 Prop. 1994/95:123, pp. 59 and 168.

70 Prop. 1994/95:123, pp. 58 and 168.

71 Patent and Market Court of Appeal PMT 5365-17 and PMT 3854-18, and several decisions from the Market Court. See judgments of the CJEU in C-210/96 (Gut Springenheide), para. 31; and C-342/97 (Lloyd), para. 26.
} 
public. $^{72}$ Thus, assessing whether a product is known is based on the same principle as trademark law: considering investments, market share, geographical area, number of sales and time on the market. ${ }^{73}$ To show perception by the relevant public, market surveys have been submitted, but the evidential value must be carefully considered in each case. ${ }^{74}$ The requirements for being known lead to it being impossible to gain protection for products not yet launched in the market, no matter how distinctive or how unfair the exploitation may be. ${ }^{75}$ The criterion for being known in the market seems hard to prove.

Furthermore, it can be difficult to draw the line between the two conditions distinctive and known. ${ }^{76}$ If a product in itself is regarded as being distinctive, but is not said to be known within the relevant sector of the public, the line between these two terms is crucial. ${ }^{77}$ In a case of alleged copying of hair products, the packaging was proved to be distinctive, but was not known within the relevant sector of the public and was therefore not unfair copying. ${ }^{78}$ Due to the influence of trademarks, the criterion of being known seems in fact like a requirement to be well known.

The third criterion is that only a product that can easily be confused with the original can be misleading. ${ }^{79}$ If consumers mistake the copied product for being the original one or assume that the products have the same commercial origin, it constitutes confusion that is misleading. The normal buying situation is of vital importance when interpreting a risk of confusion, e.g. when assessing how the products are shown in the store, or when displayed in their packaging. The benchmark in these overall assessments of the products is the perception by the relevant sector of the public. ${ }^{80}$ The assessments will take into account whether the products are groceries or luxury products, as well as the potential brand awareness. Even though the alleged infringing company has put its own mark on the product, this may not neutralize a risk of confusion, due to an overall impression. ${ }^{81}$ What stays behind in the mind of the average consumer when seeing the products, the principle of the lasting memory image (bestaiende minnesbild), is decisive. ${ }^{82}$ On the other hand, if the packaging has a design that to a great extent differs from the original, there is then no risk of confusion, even where the original product is known

\footnotetext{
72 C-108-109/97 (Windsurfing Chiemsee), para. 52; and C-375/97 (General Motors), para. 26. See MD 2004:26, MD 2008:8, MD 2015:11, MD 2016:7 and MD 2016:11.

73 MD 2004:9, MD 2006:1 and MD 2016:11; and Patent and Market Court of Appeal PMT 5365-17 and PMT 3854-18, p. 21. See Bernitz et al. (2017), p. 360.

74 MD 2011:1 and MD 2012:10. See Viken (2012); and for an analysis of decisions in the Market Court, see Viken (2017), p. $635 \mathrm{ff}$.

75 Levin (2017), p. 287.

76 Levin (2017), p. 287. See MD 1983:23.

77 Patent and Market Court of Appeal PMT 5365-17 and a number of decisions of the Market Court.

78 Patent and Market Court of Appeal PMT 5365-17.

79 Bernitz et al. (2017), p. 360.

${ }^{80}$ Nordell (2005), p. 433 ff. See judgment of the CJEU in C-251/95 (Sabel), para. 23; and C-342/97 (Lloyd), para. 25.

81 First stated in MD 1972:10.

82 Levin (2017), p. 294; and Bernitz et al. (2017), p. 360. Seen in a number of decisions of the Market Court.
} 
and distinctive. ${ }^{83}$ As the assessment is tailored to each individual case, the court might end up with different results when questioning a risk of confusion for the same original product. ${ }^{84}$

Even if the copying is found to be misleading, it is unfair only if it affects or probably affects the recipient's ability to make a well-founded transaction decision ( $§ 6$ and $8 \mathrm{MA}){ }^{85}$ The transaction test based on the UCP Directive is decisive when considering copying, even being implicitly accepted as legal doctrine in Sweden before implementation of the directive. ${ }^{86}$

Free riding on the reputation of the original product, in relation to good marketing practice in $\S 5 \mathrm{MA}$, has been pleaded in addition to $\S 14$. To be protected by $\S 5$ from free riding by others, it is a prerequisite that the original product is known and combined with a specific commercial origin. The Patent and Market Court of Appeal stated in a case concerning copying of hair products that, due to the fact that the original product was not known in the market, it could not be a question of free riding on the original reputation based on $\S 5 .{ }^{87}$ It is thus not enough that the alleged unfairly copied product reminds the consumer of the original; there must be a specific link and association between them. ${ }^{88}$

From the original trader's standpoint, it is not easy to gain protection for products under Swedish case law, since it requires products to be well known, as well as almost exact copies, before prohibiting copying. ${ }^{89}$ The public interest in free competition, avoiding monopoly, is emphasized in Swedish legislation. ${ }^{90}$

\subsection{Denmark}

In Denmark, the regulation of unfair copying of products is interpreted as a question of a breach of "good marketing practice" in the general clause, laid down in the Marketing Practices Act (MPA), with $§ 3$ stating: ${ }^{91}$

\section{$\S 3$ Good marketing practice}

3 (1) Traders shall exercise good marketing practice with reference to consumers, other traders and public interests, but see subsection (3).

\footnotetext{
${ }^{83}$ MD 2006:3 and MD 2006:7. For copying of packaging in itself there might be other assessments, see MD 1995:9, MD 2003:7, MD 2003:17, MD 2003:22, MD 2005:12 and MD 2010:4.

${ }^{84}$ E.g. the results considering copying of the Lego toy bricks differed in MD 2006:3 and MD 2004:23. For the Maglite flashlight, the results differed in MD 2008:15 and MD 2007:16 from MD 2005:6. For taxi marks, the results differed in MD 2007:2, MD 2007: 24 and MD 2007:25.

85 See preparatory works, Prop. 2007/08:115, p. 102, and SOU 2006:76, p. 240. From case law MD 2008:15, MD 2009:33, MD 2010:4, MD 2011:16, MD 2011:17 and MD 2016:7. See also Nordell (2011), p. $547 \mathrm{ff}$; and Bernitz et al. (2017), p. 361.

86 Nordell (2011), p. $547 \mathrm{ff}$.

87 PMT 16822-15.

88 MD 2016:11.

89 Bernitz (2006), p. 197.

90 Levin (2017), p. 297. See, for trademarks, the CJEU in C-299/99 (Philips), paras. 77 and 80; and C-48/ $09 \mathrm{P}$ (Lego), paras. 40 and 43.

91 Marketing Practices Act No. 426 of 3 May 2017. In force replaced LBKG 2012-01-20, No. 58, Bet 1966416 22, Bet 197368119.
} 
The reference to $\S 3$ subsection (3) concerns commercial practices affecting the consumer's economic interests in MPA part 2, as an implementation of the UCP Directive. Specific rules of good commercial practice vis-à-vis consumers are stated in MPA $\S 4(1)$. In order to clarify the distinction between consumer protection and the relationship among traders, MPA $\S 3(1)$ regulates business practice and situations where consumers' economic interests are not affected, while MPA $\S 4$ regulates unfair business vis-à-vis consumers. Furthermore, Danish law has specific regulations on business identifiers in MPA $\S 22$, stating that where a business identifier does not belong to the proposed users, it cannot be used by them, nor can they use any that they do own in a manner likely to cause confusion with those of others. $^{92}$

Due to the discretionary-based nature of the rule in MPA $\S 3$, where the criteria are set out in case law, the most important legal sources will be decisions from the Supreme Court and the Maritime and Commercial Court. ${ }^{93}$ From 2007 onwards, there was a change in the procedural system and since then copyright and marketing cases have then pleaded before district courts, at first instance, and not before the Maritime and Commercial Court. ${ }^{94}$ Appeals from a district court pass to either the High Court of Western Denmark or the High Court of Eastern Denmark.

MPA $\S 3$ as a general clause and a legal standard is meant to be dynamic and flexible and interract with business practice as it emerges at any given time. ${ }^{95}$ Provided a loss in value can be stated if a product is being copied, there are no limitations on what kind of product should be protected, including concepts. ${ }^{96}$

In general, assessment of good marketing practice in MPA $\S 3$ is meant to include considerations of the balance between the interests of traders, consumer interest, the interest in free competition, the risk of monopoly, and public interests. ${ }^{97}$ Prohibition against copying must be anchored in a fair balance of interests and critera, interpreted by case law. Due to the flexible rule, several elements can be considered. ${ }^{98}$ It is pointed out in case law that almost any product is to some extent inspired by an existing design and suitable shape in other products, and only unfair exploitation of others' efforts should be protectable. ${ }^{99}$

Case law has clearly expressed an absolute criterion of only offering protection to products that are distinctive. ${ }^{100} \mathrm{~A}$ product which has gained an identity in the

\footnotetext{
92 MPA $\S 22$ is typically used for local protection in special markets, see Borcher and Bøggild (2013), p. 478 ff.; and Møgelvang-Hansen et al. (2017), p. 259.

93 Borcher (2009), p. $151 \mathrm{ff}$.

94 Schovsbo (2011), p. 166.

95 Møgelvang-Hansen et al. (2017), p. 63.

96 The Supreme Court U1968.576H and the High Court of Eastern Denmark U1999.1762Ø.

97 Preparatory works in Bet 1992123622 f., and Bet 197368113 f. and 17. See Borcher (2003), p. 173 ff., Borcher and Bøggild (2013), p. 61; and Madsen (2019), p. 20.

98 Borcher and Bøgghild (2013), p. 65.

99 The Supreme Court U2004.835H and U2007.951H, and the Maritime and Commercial Court U1979.844S, U1996.744S, SHD08/06 V21/94, SHD21/12-00 V63/99 and SHD23/5-07 V121/05. See Koktvedgaard (1965), p. 356; and Schovsbo (1996a), p. 170.

100 The Supreme Court U2001.1006H, U2003.694SH, U2004.835H, U2007.951H, U2012.1983H and U2013.2636H, and several decisions of the Maritime and Commercial Court. See Madsen (2019), p. 168.
} 
market, due to a trader's independent effort or extensive use of the product, may fulfil a criterion of distinctiveness, e.g. a rubber boot was considered distinctive due to high quality, independent design and choice of material. ${ }^{101}$ Distinctiveness seems to be accepted even for products with low innovative value, such as furniture and clothing. ${ }^{102}$ It is not required to prove that the product is well known in the relevant market in order to gain protection. ${ }^{103}$ When assessing distinctiveness, perception of the relevant sector of the public may be taken into account, but assessments are also based on statements from expert witnesses (syn og skøn). ${ }^{104}$ Danish law seems to focus more on the physical appearance of a product than on perception in the market. An exception for functional elements is also interpreted by Danish case law. ${ }^{105}$

If the product fulfils the criterion for distinctiveness, it is a question of whether the alleged infringer is in breach of good marketing practice due to disloyal behaviour on the part of the alleged infringer. A prerequisite for applying marketing rules to a case of copying is the need to demonstrate the existence of an actual or potential competitive relationship between manufacturers of products, having a certain degree of substitutability for one another. ${ }^{106}$ A trader with the intention of copying the product by parasitically exploiting the original effort of another trader is likely to be in breach of good marketing practice. ${ }^{107}$ It will not be stated to be bad faith if a trader by his own efforts develops a similar product without knowledge of the existing product. ${ }^{108}$ The trader should, in developing his product, create a distinct difference from the original product, in order to avoid prohibition.

Close copying indicates bad faith and for products with a low level of distinctiveness, such as fashion products, arts and crafts, the Supreme Court seems to have established protection only if the copy is a slavish imitation or almost exact copy (meget nergaiende efterligninger). ${ }^{109}$ For products that are either well known, have a status as an exclusive product due to quality and material, or are expensive, a cheaper product with low quality is considered not to be slavish imitation. ${ }^{110}$

\footnotetext{
101 The Maritime and Commercial Court SH2016.V-25-15. See Madsen (2019), p. 167.

102 The Supreme Court U1995.1H, U2004.737H, U2004.1302H and U2008.446H, and several decisions of the Maritime and Commercial Court.

103 Borcher (2003), p. 164.

104 The Supreme Court U1994.671H, U1999.786H and the Maritime and Commercial Court U.1999.1061S, SH2018.T-3-16 and U2019.4235.

105 The Supreme Court U1994.072H, U2001.1843H, U2004.835H, U2007.2053H and U2014.3539H, and the Maritime and Commercial Court U2019.4235S.

106 Borcher and Bøggild (2013), pp. 72-73; and Madsen (2019), p. 173.

107 Koktvedgaard (1965), pp. 365-367; Borcher (2003), pp. 178-181; Borcher (2009), p. 151 ff.; HeideJørgensen (2017), p. 393; and Madsen (2019), pp. 161 and 177.

108 The Supreme Court U1941.454, U1986.39 H, U1999.786H and U2014.3539H, and several decisions of the Maritime and Commercial Court. See Borcher and Bøggild (2013), pp. 73-75; and Madsen (2019), p. 176.

109 Rosenmeier and Schovsbo (2015), p. $181 \mathrm{ff}$.

110 The Supreme Court U2008.1834H and U2013.759H, and the Maritime and Commercial Court SH2016.V-24-15, SH2016.V-25-15, SH2016.V-38-15 and SH2016.A-29-16.
} 
There is also the question of whether risk of confusion is to be interpreted as an explicit criterion or as an element to be considered in an overall assessment of MPA $\S 3{ }^{111}$ Case law is not consistent, but in a landmark decision from 2008 , concerning the alleged copying of desk drivers for furniture sold to professionals, the Supreme Court interpreted a risk of confusion as a decisive element in determining whether or not there was unfair copying. ${ }^{112}$ The decisions must be interpreted as meaning that it was not sufficient to state physical similarities between the products, interpreting a risk of confusion as an explicit criterion. ${ }^{113}$ The decision seems not to have been followed up by lower courts, which are still taking into account slavish imitation, without mentioning a risk of confusion. ${ }^{114}$ Whether or not a risk of confusion is an explicit criterion or simply an element in the overall assessment is unclear.

When assessing a risk of confusion, association with a specific original brand in the relevant sector when seeing the newcomer's product may indicate unfair copying of the original product. ${ }^{115}$ On the other hand, different packaging does not neutralize a risk of confusion, because it is the product in itself which is to be assessed. ${ }^{116}$ In some cases, the court compares the products physically and decides on a risk of confusion without basing it on the perception of the relevant sector of the public. ${ }^{117}$ The courts seem to put more emphasis on direct comparison between the products based on expert statements (syn og $s k \phi n)$ than on the perception by the relevant sector of the public. ${ }^{118}$ Assessments of a risk of confusion can also be combined with the question of distinctiveness. ${ }^{119}$ In an overall assessment, other elements may be assessed as a breach of good marketing practice, e.g. former relationships or employment, or free riding. ${ }^{120}$

The complex relationship between slavish imitation and a risk of confusion can be illustrated by a case concerning the copying of porcelain, where the court stated that the design of the two porcelain products was, to a great extent, a slavish imitation and therefore led to a risk of confusion. ${ }^{121}$ For well-known products, a specific question is raised in Danish legal theory. If customers choose to buy a cheap

\footnotetext{
$\overline{111}$ Borcher and Bøggild (2013), p. 76; and Madsen (2019), p. 170.

112 U2008.1834H. See Borcher (2009), p. 151 ff.; and Madsen (2019), p. 171.

113 Supreme Court U2011.2736H, U2012.129H, U2012.1185H and U2013.759H.

114 The Maritime and Commercial Court SH2016.V-25-15, SH2017.A-4-17, SH2018.V-41-17 and SH2019.BS-10889/2018.

115 The Supreme Court U2008.446H, and the Maritime and Commercial Court U2009.233S.

116 Borcher and Bøggild (2013), pp. 65 and 79.

117 The Supreme Court U2013.759H, and the Maritime and Commercial Court SH2016.V-73-15 and U2017.3607S. See Borcher and Bøggild (2013), p. 78.

118 The Supreme Court U1981.775SH, U1994.671/2H, U1995.1/2H, U2008.446H, U2012.3584H, U2012.1185H, U2013.759H and U2014.3539H, and High Court of Western Denmark U2014.2237. See Borcher and Bøggild (2013), p. 78; Møgelvang-Hansen (2017), p. 531; and Madsen (2019), p. 170.

119 The Supreme Court U2001.1006/2H and U2008.1834H.

120 The Supreme Court U1974.463H, U1975.1049H, U2006.1209H, U2006.2697H and U2013.759H, and the Maritime and Commercial Court U1982.1149S and SH2018.V-67-17. See Koktvedgaard (1965), p. $274 \mathrm{ff}$.

121 The Maritime and Commercial Court U2017.110S.
} 
copy of a well-known high quality product, well aware that it is a copy, there is no risk of confusion and it is harder for the original trader to gain protection. ${ }^{122}$ It is stressed in these cases that the trader might have been better off with an assessment of slavish imitation than a risk of confusion.

As there are no cumulative criteria listed in MPA $\S 3$, the courts have elaborated that the trader behind the original product must prove that it is a case of copying, that the developed product is distinctive based on his own independent effort, and that the alleged infringer has shown disloyal behaviour concerning an illicit, in some cases slavish, imitation of the original product. To what extent it is a criterion for a risk of confusion is stressed in some cases, while others base the assessment on slavish imitation. The focus in Danish law seems to be protection of market positions gained by independent effort. ${ }^{123}$

\section{A Unified Scandinavian Marketing Approach?}

\subsection{Structure and Positioning of the Rules}

Structure and positioning of the regulations on the copying of products may in itself reveal a differentiated approach to the borderline between legitimate and unfair copying.

In the European countries, national legislation on unfair competition is structured in different ways. ${ }^{124}$ Finland, for example, has chosen a split in its marketing laws, regulating the relationship between competitors in the Unfair Business Practices Act, while rules on consumer protection are placed in the Consumer Protection Act. ${ }^{125}$ Copying of products is not regulated in a specific rule in the Finnish Unfair Business Practices Act, but is interpreted as a breach of the general clause in case law from the Market Court. Another example is the German Act Against Unfair Competition, which regulates both business practice and consumer protection. ${ }^{126}$ The German Act has a specific rule on protection of competitors, and replicas of goods or services can be considered a breach of Sect. 4 No. 3. A third example is the United Kingdom, which is said to have no general law against unfair competition or copying of products. ${ }^{127}$ Even though the Paris Convention Art. $10^{\text {bis }}$ has never been transposed into domestic legislation, the United Kingdom has other legal mechanisms, including legislation on consumer protection, the common law torts of passing off and malicious falsehood and the equitable claim for breach of confidence. ${ }^{128}$

\footnotetext{
122 Borcher (2009), p. $151 \mathrm{ff}$.

123 The Supreme Court U1999.1859H, and the Maritime and Commercial Court U1995.92SH. See Madsen (2019), p. 167.

124 For an overview, see Henning-Bodewig (ed.) (2013).

125 Acts 1061/1978 and 38/1978. See Henning-Bodewig (2006), p. 105 ff.; and Engelbrekt (2007), p. 164.

126 Act Against Unfair Competition in the version published on 3 March 2010, as last amended by Art. 5 of the Act of 18 April 2019 (Gesetz gegen den unlauteren Wettbewerb - GWB).

127 Henning-Bodewig (ed.) (2013), p. 603; and Arnold (2013), p. 73 ff.

128 Arnold (2013), p. 65.
} 
As for the Scandinavian countries, marketing laws in all three countries enact regulations on the copying of products, but the positioning of the regulations gives an immediate impression of differences.

In Norway, the specific rules regarding unfair competition are placed in a separate chapter in the law on marketing, concerning business practice among traders. ${ }^{129}$ Thus, the focus on unfair copying in Norway is on the trader's practice in business society. The same applies in Denmark, where the copying of products is interpreted in the general clause as a question of good marketing practice concerning business-to-business. ${ }^{130}$ The division between a breach of good marketing practice among traders and commercial practices vis-à-vis consumers is clarified in MPA $\S 3$ (business) and MPA $\S 4$ (consumers) respectively.

In Sweden, provisions on copying are found among other rules regarding misleading marketing which affect consumers' economic behaviour, with a basis found in the UCP Directive. Even though copying is stated as being misleading, based on $\S 14$ MA, it is not regarded as unfair copying if it does not affect, or probably does not affect, the recipient's ability to make a well-founded transaction decision ( $\$ 8 \mathrm{MA}$ ). The Swedish solution, using the consumer transaction test in cases concerning unfair competition, is criticized in legal journals, since it is argued that this practice may be in conflict with the UCP Directive in an area of nonharmonized EU law. ${ }^{131}$ While the consumer transaction test is an incorporated part of the assessment of copying of products in Swedish courts, I have not found cases in Norway or Denmark where consumers' economic behaviour was decisive in the same way in assessing unfair copying among traders. On the contrary, it is explicitly stated in Danish law that marketing which affects consumers' economic behaviour is regulated by other rules. ${ }^{132}$ Thus, a striking difference between Norway and Denmark on one side, and Sweden on the other, is in the assessment of consumers' economic behaviour when considering unfair copying among traders.

A different interpretation might also be explained by the timing of the implementation of the rules on copying. While a specific rule on copying, with cumulative criteria, was established in Norway in 1972, both Sweden and Denmark decided to implement general clauses. Sweden did not enact a specific rule until 1995, codified and based on restrictive case law from the Market Court. Today, Norway and Sweden have specific regulations stating that prohibition only applies if cumulative criteria are fulfilled; the opposite of the discretionary general clause in Denmark. Even though the Danish solution allows for broader and more flexible assessments, the courts seem to affirm criteria in much the same way as in Norway and Sweden. Nevertheless, a thorough analysis reveals differences when weighing up the elements in the assessments of copying of products, e.g. uncertainty connected to the relationship between slavish imitation and risk of confusion in Danish courts.

\footnotetext{
129 Rules concerning marketing which directly affect consumers are regulated in MCA ch. 2-5.

130 MPA $\S 4$, commercial practices vis-à-vis consumers are to be considered based on part 2 of the MPA.

131 Nordell (2011), p. 557; and Bernitz (2006) pp. 127-146.

132 MPA part 2 is applied in consumer cases.
} 
The Danish general clause is open to inconsistency and more unpredictable rules for traders. The so-called cumulative criteria in Norway and Sweden might also give grounds for uncertainty. In specific terms, the unclear distinction between the Norwegian specific rule on unfair copying of products, and the breach of good business practice in the general clause, leaves an opening for uncertainty. Inconsistency in case law makes it necessary for the original trader to plead infringement based on both rules, as a safety net. The general clause in Sweden is pled for other reasons than copying in itself, e.g. free riding on another's effort. In Danish law, all issues can be considered as a breach of the general clause, balancing the interests of traders, consumers and society.

Due to different structures and positions, it can be questioned whether there are differentiated approaches in the Scandinavian countries when assessing the borderline between legitimate and unfair copying of products. The seemingly differentiated assessment of what is a fair balance between the public interest in free competition and the protection of a trader against unfair competition opens to question the rationale behind this.

To examine potential different assessments, a closer look must be taken at the protection of the traders' investments and goodwill connected to infringement assessments, as well as the broader perspective based on a market-oriented approach. It will also be examined how each country approaches the tension between the marketing rules outside the boundaries of intellectual property protection and the principle of legitimate copying.

Considering that protection outside the boundaries of intellectual property is tailored to each individual case, any examination of approaches by the Scandinavian countries must be done with some restraint. Attempting to find similar starting points for comparison, I will to some extent use the example of Lego-related cases from each country as a backdrop for my analysis.

\subsection{Protection of Investments and Goodwill}

The manner in which protection of the original traders' investment and products' goodwill are weighed when considering disloyal behaviour from competitors in a free market economy could reveal diverging attitudes towards the concept of copying. The view stating that "reaping without sowing" is unfair is found in courts in Continental Europe, while other European countries emphasize free competition and legitimate copying. ${ }^{133}$ An example of the latter is the United Kingdom, even though passing off has been recognized as a legal ground for unfair copying outside the scope of intellectual property. ${ }^{134}$

The wording in Norwegian law, "unfair exploitation" of "effort or results", emphasizes protection of the original trader who invested in the product, set against unfair behaviour. Economic investments in time and resources, capital input and marketing costs are examples of protectable effort. The first Lego case in Norway, assessing copying of the original toy bricks from Lego, can serve as an illustration

\footnotetext{
133 Ohly (2010), pp. 507-508.

134 Arnold (2013) p. $73 \mathrm{ff}$.
} 
of the importance of protecting investments. ${ }^{135}$ The Supreme Court stated that Lego had extracted its earnings potential in the market and had covered the costs related to development of the Lego bricks, and therefore the product was not protectable. Some inconsistency is revealed in the second Lego case, where the toy bricks were considered protectable by the lower court. ${ }^{136}$ All in all, infringement assessment and behaviour considered as disloyal are important elements when considering unfair copying, even though culpability is not required in Norway. ${ }^{137}$

A focus on traders and fair behaviour among traders due to "good marketing practice" is also considered important in Denmark. ${ }^{138}$ An actual or potential competitive relationship between the manufacturers of the products is required in order to constitute unfair copying. ${ }^{139}$ It is pointed out that the trader's market position, its gained identity in the market and the independent effort behind the development, which resulted in a distinctive overall impression of the product, should be protected. ${ }^{140}$ In contrast to the Norwegian Lego case, the Danish court stated in the second Lego case that extensive product development and effort had resulted in a market position considered as being protectable. ${ }^{141} \mathrm{~A}$ comparison with the Norwegian case is interesting, due to the fact that they were both settled in the mid-1990s, assuming there were similar markets in Denmark and Norway. At the time, the Danish courts seemed to place more emphasis on protecting market position.

The assessment of what is protectable under Swedish law relates to products being "known and distinctive" in the market, in the same way as in trademark law, taking into acount investments, market share, geographical area, number of sales and time on the market. ${ }^{142}$ Investment is one element, but there seems to be a broader perspective in Sweden. As for the question of protecting the Lego brick in Sweden, the assessment differs from the Norwegian approach. Whereas in Norway, the trader's investment was in focus when considering protection of the Lego toy bricks, the Swedish approach was connected to the market perception, based on the fact that the Lego brick was distinctive and known in the market. ${ }^{143}$ In the Danish courts, it is emphasized that the trader's effort has resulted in a protectable market position. Seemingly, interpretation of what is "misleading" and "unfair" in Sweden is mostly based on market perceptions and consumers' economic behaviour.

\footnotetext{
135 The Supreme Court Rt 1994, p. 1584 (Lego 1).

136 The Court of Appeal LB-2006-3616 (Lego 2).

137 Preparatory works, Innst. Konkurranselovkomiteen 1966, p. 31, and Supreme Court Rt. 1998, p. 1315 (p. 1322); and Stenvik (2006), p. 15; Helset et al. (2009), p. 575; Lunde (2001), pp. 268-269; Wold (2010), pp. 140-141; Rognstad (2019), p. 163.

138 The Supreme Court U1999.1762H.

139 Madsen (2019), p. 173; and Borcher and Bøggild (2013), pp. 72-73; Lunde (2001), p. 40.

140 Madsen (2019) p. 167. The Supreme Court U2001.1006H, and the High Court of Eastern Denmark 2018 in case B-1259-17.

141 The Maritime and Commercial Court U1995.92S (Lego 2). In the first Lego case the Supreme Court found that slavish copying had not occurred, see U1961.46H (Lego 1). See Schovsbo (1996b), p. 33 ff.; and Madsen (2019), pp. 187-189.

142 MD 2004:9, MD 2006:1, MD 2016:11 and PMT 5365-17.

143 MD 2004:23 (Lego I) and MD 2006:3 (Lego II).
} 
Protecting traders' investments and goodwill in Norway seems to be important in weighing the balance between unfair behaviour by the alleged infringer and the effort invested by the original trader. In Denmark, a potential competitive relationship and protection of market position are valued highly in balancing interests. Thus, marketing rules in Norway and Denmark focus on the behaviour of the alleged infringer based on subjective elements, seemingly given more weight than the principle of free competition. ${ }^{144}$ In Sweden there is not the same focus on the traders' behaviour and subjective elements as such, instead placing more weight on the consequences for consumers and the market, and less focus on the traders' interests and disloyal behaviour.

\subsection{Market-oriented Approach}

A market-oriented approach, weighing perception in the market and the customer's view as important elements in assessing the copying of products, might reveal a steady course in the direction of emphasizing public interest in free competition.

While unfair copying under Swedish law relates to the product being distinctive and known, based on a market-oriented approach, it is not even clear to what extent there is a requirement for distinctiveness in order to protect products in Norway. The emphasis is on protectable effort or result, such that it appears that traders' investments $o r$ the result connected to the products' goodwill could be protectable. There is no requirement for products to be known. In Denmark, distinctiveness is a requirement, but with acceptance extending to products of low innovative value and simple products this is not a strict criterion. An assessment of unfair copying in these cases requires slavish imitation. The focus seems to switch from market perception to considering imitation, based on expert statements (syn og sk $\phi n$ ). Assessments are not market-oriented to the same extent as in Sweden.

In reality, Swedish law requires the product to be well known in order to be protected, being quite strict from the original trader's point of view, so quite opposite in approach to Norway and Denmark. ${ }^{145}$ In Sweden, a market-oriented approach stresses freedom of imitation to a greater extent.

The average consumer's perceptions of the product or marketing are a benchmark in all three countries. As for assessing a risk of confusion, with a basis in Paris Convention Art. $10^{\text {bis }}(3)$ No. 1, there seem to be slight differences between the countries. In assessing a risk of confusion in Sweden, what remains in the consumer's mind when not seeing the products is decisive, again influenced by trademark law. In addition, the consumer transaction test puts emphasis on the market-oriented approach. Another element is that Swedish law prohibits products that can easily be confused with the original, while the wording in Norwegian law is risk of confusion. It could be questioned whether this opens the way for a stricter interpretation in Swedish law, but seemingly it is interpreted in the same way in both countries.

\footnotetext{
${ }^{144}$ Helset et al. (2009), p. 538.

145 Borcher (2003), p. 50.
} 
The unclear distinction between slavish imitation, based on a physical comparison undertaken by experts, and assessment of a risk of confusion in the relevant sector of the public is challenging for Danish courts. ${ }^{146}$ It would appear that the courts place more focus on a physical comparison between the products, based on expert statements, rather than a market-oriented focus. Norway and Denmark, unlike Sweden, do not adopt the trademark point of view when assessing a risk of confusion. $^{147}$

There are also examples of a more market-oriented approach in both Norway and Denmark. A series of cases concerning the alleged copying of rubber boots in Denmark, where the alleged copyist had developed a product of lower quality and lower price, can serve as an illustration. ${ }^{148}$ The court concluded that the quality of material of the original rubber boot made for a more elegant design and gave the product a specific identity in the market, and that the cheaper copy was therefore not an imitation. The same applies to a case in the Court of Appeal in Norway, finding that consumers would not confuse products meant for the high-end market with a cheaper product meant for the lower end of the market. ${ }^{149}$ Another element is that regulations on unfair copying are not supposed to reduce consumer choice. ${ }^{150}$ In the Lego case, the Norwegian Supreme Court took into account a balance between the trader's interest in protecting the product and consumers' interest in having a free choice of products, when considering whether there was unfair copying. ${ }^{151}$ Based on a market-oriented approach, this is in line with a requirement for a risk of confusion, securing consumer choice and free competition.

In the aftermath of such cases, a fundamental scepticism in Danish legal theory is revealed, focusing on protection of well-known products, where customers choose to buy the copy, not the original product, well aware that it is a copy. ${ }^{152}$ Based on considerations by the relevant sector of the public, a low price is more important than exclusive design and high quality material, and they choose to buy the substitute. The criticism in Denmark is connected to the original trader's view in protecting effort and market position, stating that the trader would have been better off with an assessment of slavish imitation than a risk of confusion. Again, the uncertainty under Danish law raises the question of what is acceptable as legitimate copying. Furthermore, slavish imitation is problematic, because it is the same criterion as in intellectual property law. ${ }^{153}$

The extent to which the newcomer manages to differentiate the product and neutralize similarities is considered in all three countries. In the first Lego case in

\footnotetext{
$\overline{146}$ Borcher and Bøggild (2013), pp. 61 and 78. See the Supreme Court U2008.446H, U2012.3584H, $\mathrm{U} 2012.1185 \mathrm{H}$ and $\mathrm{U} 2013.759 \mathrm{H}$.

147 Rt 1979, p. 758. See Lassen and Stenvik (2006), pp. 381-382.

148 The Maritime and Commercial Court SH2016.V-25-15, SH2016.V-24-15, SH2016.V-38-15 and SH2016.A-29-16.

149 RG 1986, p. 1010.

150 UCP directive preamble 14. See Ohly (2010), pp. 517-518.

151 Rt. 1994, p. 1588.

152 Borcher (2009), p. $151 \mathrm{ff}$.

153 Ohly (2010), p. 520.
} 
Sweden, the sale and marketing of toy bricks were prohibited, because the product did not differ from the original. ${ }^{154}$ In the second Lego case, a risk of confusion was concluded as being neutralized, because the packaging differed from the original. ${ }^{155}$ The same approach was applied in the second Lego case in Norway, where it was stated that if the product name and/or the packaging of the alleged copied product was very different from the original, there was no risk of confusion. ${ }^{156}$ This is the opposite of the approach in Denmark, where the courts do not accept an attempt to neutralize similarities by using different packaging or branding. ${ }^{157}$

Opposite to the position in Norway and Denmark, Swedish law seems to put more weight on assessements of perception in the relevant sector of the public, with a market-oriented approach, including the consumer transaction test. This is more in line with the principle of a free market economy and freedom of imitation.

\subsection{Approaching the Boundaries of Intellectual Property Protection}

Modification of the principle of legitimate copying outside the boundaries of intellectual property protection can be discussed on the basis of three different approaches. ${ }^{158}$ One approach is viewing regulations on unfair copying as being unavailable outside the scope of intellectual property law. An alternative approach would be that regulations on unfair copying and intellectual property are considered as being equal to and independent from each other. A middle approach is that an achievement that does not infringe intellectual property can then be rendered unfair only if certain aggravating circumstances arise in the individual case, stating that imitation as such is permissible. ${ }^{159}$

The CJEU in the Lego case commented that the rules on unfair competition, where appropriate, can be examined as legal grounds for protection outside the scope of intellectual property. ${ }^{160}$ When assessing unfair copying of the Lego brick in Scandinavia, the courts considered marketing laws as a supplement to intellectual property protection. As for the question of trademark protection raised in the CJEU, the Lego brick was declared incapable of such protection for the reason that the basic brick was necessary to obtain a technical result. In Scandinavia, an exception for functional elements is either spelled out in the wording of the law or interpreted as a presumption in marketing rules on copying of products. To what extent unfair copying is justified as a supplement to intellectual property protection in other areas might differ among the European countries. I will therefore examine the extent to which there is a unified Scandinavian approach to how marketing rules relate to intellectual property law.

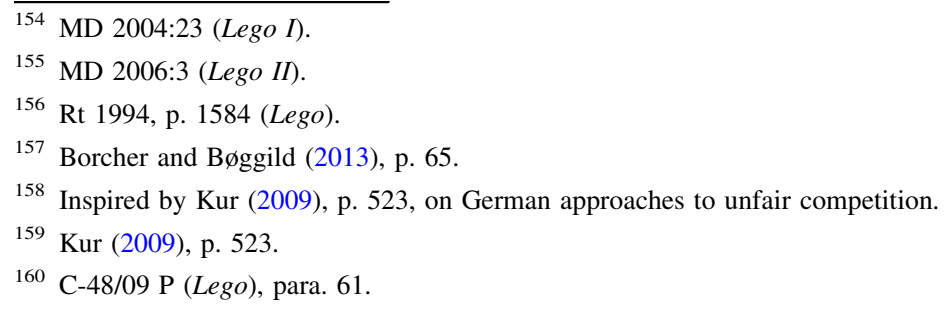


A starting point in Danish law is that the general clause must be set aside if there are specific rules covering the situation. ${ }^{161}$ Infringement must be found in other elements outside the scope of intellectual property for it to be considered as a breach of marketing law. ${ }^{162}$ It is also argued that protection against slavish imitation under marketing rules is compatible with intellectual property law, being of a different kind and arising in a different manner with different content. ${ }^{163}$ Marketed products, well established with a certain market value, can be protected, even though only with a narrow protection that addresses only close imitations and lasts only while the market value is preserved. ${ }^{164}$ Furthermore, it is stated that the regulation of unfair copying of products is the most important alternative to copyright or design protection for arts and crafts, if the criterion set out in intellectual property law is not fulfilled. ${ }^{165}$ Thus, the courts in a number of cases have concluded that the product did not infringe exclusive rights, but was instead a breach of unfair copying, based on the general marketing clause. ${ }^{166}$ In practice it is a two-step session, with infringing intellectual property law as the principal claim, and breach of good marketing practice as a subsidiary claim. ${ }^{167}$ There are also many examples of decisions stating breach of both copyright or design and marketing rules. ${ }^{168}$ The Danish courts also choose between intellectual property law and marketing rules, taking the direction of seeing the marketing rules as an independent alternative to intellectual property law. ${ }^{169}$ The picture is not clear, and the Maritime and Commercial Court has, in new decisions, when ruling on a claim for protection based on both copyright and marketing law, stressed that it was not necessary to consider a breach of marketing rules in addition to copyright. ${ }^{170}$

In Norwegian cases, there is a tradition of a three-step legal procedure in litigation concerning copying. First, the original trader may plead infringement of an exclusive right as the main allegation, while in the next step claiming unfair copying of products based on the specific marketing rule, and thirdly claiming a breach of good business practice in the general clause. If the criterion for infringing

\footnotetext{
161 Kogtvedgaard (1965), pp. 353 and 389. Borcher and Bøggild (2013), p. 63.

162 The Supreme Court U1986.39H, U2002.1715H, U2006.600H, U2012.3189H and U2012.1185H.

163 Engelbrekt (2007), p. 169; and Heide-Jørgensen (2017), p. 390.

164 Heide-Jørgensen (2017), p. 390.

165 The Supreme Court U2013.694SH (supplementing copyright) and U1999.786H (supplementing design). See Borcher and Bøggild (2013), p. 62.

166 The Supreme Court U1999.786H and U2014.3346H, the Maritime and Commercial Court U2003.694S, SH2010.V-6-09, SH2017.A-4-17, SH2018.V-41-17 and SH2019.BS-10889/2018, the High Court of Western Denmark U2014.2237V, and the High Court of Eastern Denmark U1999.1762Ø. See Madsen (2019), p. 191.

167 E.g. the Supreme Court U2014.3539H, and the Maritime and Commercial Court SH2016.V-25-15, SH2016.V-24-15 and SH2016.V-38-15.

168 E.g. the Supreme Court U2015.2011H, and the Maritime and Commercial Court U1985.1087S, U.1992.909S, U1998.941.S, SH2003.V-32-99, SH2008.V-52-07, SH2009.V-123-08, U2009.233S, U2017.110S.V-92-14, SH2019.BS-46785/2018-SHR and SH2019.BS-18539/2018-SHR.

169 E.g. the Supreme Court U2011.2736H, U2012.3584H and U2013.759H, and the Maritime and Commercial Court U.1992.345S and U1999.1859S. See Borcher and Bøggild (2013), p. 62.

170 The Maritime and Commercial Court SH2019.BS-1498/2016-SHR.
} 
intellectual property law is not fulfilled, the marketing rules may serve as a supplement to the intellectual property regulations when specific circumstances arise. ${ }^{171} \mathrm{~A}$ few decisions appear to state that the marketing rules serve as a more independent ground for infringement, outside the boundaries of exclusive rights. ${ }^{172}$ It is pointed out in legal academic articles that in Norway intellectual property rules establish exclusive rights to certain objects, while marketing rules prohibit certain behaviour in business society, but with more flexible rules. ${ }^{173}$

In both Norway and Denmark it is stated that objectively similar products cannot in themselves be protected by marketing rules outside the boundaries of intellectual property law, unless certain subjective elements are involved. ${ }^{174}$ If requirements of infringing intellectual property protection are not fulfilled, only specific circumstances outside the scope of exclusive rights can prohibit unfair copying. ${ }^{175}$

Certain links between the criteria in intellectual property law and the rules on unfair copying can be found in the presumption of intended copying in copyright law and the requirement for knowledge of the existing product in marketing law. ${ }^{176}$ A more complex relationship between intellectual property law and the unfair copying of products in marketing law can be illustrated by a Supreme Court decision in Norway, where the court seems to have stretched the limits of the risk of confusion in order to reach a desired result, in the case of copyright protection for a chair (Tripp Trapp). ${ }^{177}$ The Court seems to base its infringement assessment on a risk of confusion, basing it on elements from marketing law more than on copyright. A risk of confusion when assessing copyright infringement is also seen in the Court of Appeal. ${ }^{178}$

Due to procedural rules, the Swedish courts did not have the opportunity to consider both marketing rules and intellectual property law in relation to the same case until 1 September 2016. Swedish traders needed to choose whether they should claim on the basis of exclusive rights based on IP or misleading copying according to marketing rules or, in some instances, parallel cases. The general courts tailored their assessment of each case when considering design and copyright protection in a number of cases, e.g. in relation to protection of clothing. ${ }^{179}$ Parallel proceedings could result in products being considered as copyright protectable (verkshöjd) in the

\footnotetext{
171 Norwegian preparatory works, Innstilling fra Konkurranselovkomiteen 1966, pp. 23-24, the Supreme Court Rt 1959, p. 712, Rt 1994, p. 1584 and Rt 1998, p. 1315, and the Court of Appeal RG 1981, p. 418, RG 1998, p. 277, RG 2013, p. 961 and LE-2017-187139. See Rognstad (2000), p. 322; and Ringnes (2016), p. 765.

172 An interpretation in this direction is found in preparatory works Ot.prp. No. 57 (1971-72), p. 27. See the Supreme Court Rt. 1998, p. 1315, and the Court of Appeal RG 1981, p. 418, LF-2005-120379, LB2015-134806 and LG-2016-44586.

173 Stenvik (2013), p. 15.

174 Lunde (2001), pp. 247-248; and Madsen (2019), p. 189.

175 Rt. 1959, pp. 712, 713. For elements other than copying, see Rt. 1997, p. 199. See Ringnes (2016), p. 773; and Heide-Jørgensen (2017), p. 391.

176 LB-2018-142457. See Rognstad (2019), p. 163.

177 Rt. 2012, p. 1062. See Lund (2014), pp. 178 and 197; and Rognstad (2012), p. 19 ff.

178 RG 2006, p. 1302. See Rognstad (2019), pp. 174-175.

179 Supreme Court NJA 1995, p. 164 (NJA 1995:26), and the Court of Appeal RH 1997:13.
} 
general courts, but not as misleading copying, due to there being no established risk of confusion in the Market Court. ${ }^{180}$ Even though the Market Court had no opportunity to consider intellectual property law, there are statements showing an intellectual property direction in its thinking. ${ }^{181}$

The introduction of Patent and Market Courts in Sweden opens up the possibility of supplementing intellectual property law with marketing rules on unfair copying. ${ }^{182}$ In a case concerning the copying of electric candlesticks, both copyright and marketing rules were argued. ${ }^{183}$ One of the candlesticks fulfilled the criteria of being copyright-protected, but due to the different appearance of the alleged infringed product it was not a case of infringing copyright. The next question was whether it was misleading copying, based on $\S 14$ MA. The court concluded that the candlestick was not known in the market and therefore it was not misleading copying. ${ }^{184}$ Thus, the product was said to have copyright protection, but did not fulfil the criteria for protection according to marketing rules. Such a distinction between the requirements of exclusive rights in copyright cases and the market-oriented criterion of being known in the relevant market may raise challenging situations in Swedish courts. The extent to which we will see many combined cases in Sweden may be illustrated by a recent case concerning copying of wristwatches, where marketing rules were not pleaded as being a supplement to copyright infringement. ${ }^{185}$

The implementation of EU design law may also have an impact on national legislation on the copying of products, approaching the boundaries of intellectual property protection. Pursuant to the EU design regulation, Sweden and Denmark have implemented Art. 11 on unregistered Community designs in national statutory law for a period of three years. As this regulation is not a part of the EEA, rules on unregistered designs are not implemented within Norwegian design law. ${ }^{186}$ Striving for a unified Scandinavian approach, it is suggested that protection regarding unregistered designs will apply in the same way in Norway as in the EU. ${ }^{187}$ Even so, marketing rules on the copying of products might be of more importance in Norway than in Sweden and Denmark. ${ }^{188}$ Overall, the EU design system has been effective. ${ }^{189}$ A report concludes that the system works well, but that the awareness of the availability, benefits and ways for protecting designs in the EU is

\footnotetext{
180 The Maglite flashlight cases in Supreme Court NJA 2009, p. 159 (NJA 2009:18), and Market Court MD 2007:16 and MD 2008:15.

181 MD 2012:15. See Bernitz (2013), p. 452.

182 Levin (2017), p. 300.

183 Patent and Market Court of Appeal PMT 3854-18.

184 Patent and Market Court of Appeal PMT 3854-18, p. $20 \mathrm{ff}$.

185 Patent and Market Court of Appeal PMT 5885-18.

186 Stenvik (2006), pp. 22-23.

187 Stenvik (2006), p. 23.

188 Schovsbo and Teilmann-Lock (2016), p. 429.

189 Church et al. (2019), pp. 685-719.
} 
insufficient. ${ }^{190}$ Rules on unregistered designs raise the question of whether there is a need for marketing rules on unfair copying. ${ }^{191}$ The scope of unregistered designs seems to be stated in a narrow way, with regard to the requirements of being new and a narrow protection due to slavish imitation for all designs. ${ }^{192}$

While intellectual property infringement is to a large extent disconnected from the trader's subjective behaviour and unfair practice, marketing rules in Norway and Denmark depend on a subjective consideration of the trader's behaviour. Protection against copying may be said to be indirect, because marketing rules do not prohibit the copying in itself, but the way in which the copy is used in the market is based on subjective elements. ${ }^{193}$ In Sweden, marketing rules are to a greater extent based on the same considerations as in intellectual property law, not putting weight on subjective elements. The reasoning for a tighter link in Norway and Denmark than in Sweden, between intellectual property law and marketing rules, is the differing procedural rules.

Even though there are different approaches to marketing rules as a supplement to intellectual property law, all three countries will fit into the middle approach, requiring the existence of specific elements in order to consider the copying as being unfair. Within this group, Denmark seems more to be taking the approach of considering marketing rules as independent from intellectual property law, e.g. finding a breach of both sets of rules in several decisions. Sweden seems more to be taking the direction towards a restrictive approach, viewing marketing rules as virtually unavailable outside the scope of intellectual property. Norway seems to fit more into the middle, but it is constantly strained between the specific rule and the general clause.

\section{Concluding Remarks}

Analysis of statutory law and case law has revealed differences in the approach to copying of products in Scandinavia. By contrast to the cooperation in the 1970s, there does not seem to be a unified Scandinavian approach across all aspects. The tension between marketing rules outside the boundaries of intellectual property protection and the principle of legitimate copying is solved in slightly differing ways.

All three countries consider both perception in the market and the behaviour of traders as elements to be taken into account, but with different weightings. It seems as though the attitude towards what is a fair balance of interests differs between Norway and Denmark, on the one hand, and Sweden on the other. Sweden is more market-oriented, requiring the fulfilment of strict criteria before making a finding of

\footnotetext{
$\overline{190}$ European Commission. Public consultation. Ref. Ares (2019)4979430 - 30/07/2019. DG for Internal Market, Industry, Entrepreneurship and SMEs. Factual Summary report on the public consultation on the evaluation of EU legislation on design protection.

191 Madsen (2019), p. 191.

192 Schovsbo and Svendsen (2002), p. 40.

193 Schovsbo (2011), p. 172.
} 
misleading copying, influenced by both trademark law and the consumer's economic behaviour. A lower focus on the newcomer's behaviour leads to an approach in the direction of a true implementation of the principle of free copying outside the scope of intellectual property law. Norway and Denmark seem to assess the behaviour of the alleged infringer and the original trader's market position as being essential elements, weighing traders' interests as being more important than freedom of imitation.

The different approaches taken by the Scandinavian countries might also be criticized to some extent. The Swedish approach might be criticized due to the fact that the consumer transaction test is used in a business-to-business model, stretching the scope of the harmonized UCP Directive. The flexible Danish approach might be considered challenging, because it is less predictable for traders, as revealed by inconsistent case law. While the risk of confusion is part of cumulative criteria in Norway and Sweden, the Danish solution is to put weight on physical similarities between the products, considering slavish imitation either as an alternative or in addition to a risk of confusion. Thirdly, the Norwegian approach is open to uncertainty, due to the strain between the specific rule and the general clause, both argued in claims relating to the copying of products. A disadvantage of having marketing rules as the main regulation on copying is the consequent uncertainty. ${ }^{194}$

The investigation of the Scandinavian approach reveals a patchwork, seemingly in need of clarification, e.g. through EU harmonized rules. Furthermore, the diversified Scandinavian approach is not unique from a European perspective, with differing solutions to legislation on copying of products found among other European countries. ${ }^{195}$ A question that could be raised for further examination is connected to a potential missing link between the international framework and national legislation. ${ }^{196}$ Differences among the European countries when considering legislation on unfair copying outside the scope of intellectual property protection might in itself make it difficult to find a solution within harmonized EU rules on unfair copying. ${ }^{197}$ In addition, the EU regulation on unregistered designs and the MCA and UCP Directives will cover some of the aspects relating to unfair copying and there might not be a need for harmonized rules within the EU. ${ }^{198}$

The answer to the question raised in this article is that there is no unified Scandinavian approach, and the best choice might be to leave it up to national legislation to find robust solutions at the borderline between legitimate and unfair copying of products. The extent to which it is possible to provide a substantial contribution toward a common European legal framework governing those portions of unfair competition that presently remain fragmented remains unclear. ${ }^{199}$

\footnotetext{
$\overline{194}$ In this direction, Ohly (2018), p. 138.

195 Ohly (2010), p. 509.

196 Nordell (2017), pp. 231-232.

197 Ohly (2010), pp. 506-524. See Henning-Bodewig (ed.) (2013), for country reports from the European countries.

198 In this direction, Levin (2017), pp. 340-341.

199 In the same direction, Kur (2009), p. 533.
} 
Open Access This article is licensed under a Creative Commons Attribution 4.0 International License, which permits use, sharing, adaptation, distribution and reproduction in any medium or format, as long as you give appropriate credit to the original author(s) and the source, provide a link to the Creative Commons licence, and indicate if changes were made. The images or other third party material in this article are included in the article's Creative Commons licence, unless indicated otherwise in a credit line to the material. If material is not included in the article's Creative Commons licence and your intended use is not permitted by statutory regulation or exceeds the permitted use, you will need to obtain permission directly from the copyright holder. To view a copy of this licence, visit http:// creativecommons.org/licenses/by/4.0/.

Funding Open Access funding provided by Norwegian Business School.

\section{References}

Arnold R (2013) English unfair competition law. IIC 44:63-78. https://doi.org/10.1007/s40319-0120010-5

Bernitz U (2006) Kommentar till svenska Marknadsdomstolens avgörande MD 2006:3, LEGO v. COBI angående vilseledande efterbildning och renommésnyltning. NIR, pp 197-199

Bernitz U (2013) Varumärkesrätten i svensk marknadsrätt. Kommentar till svenska Marknadsdomstolens dom 2012:15, Elskling mot Kundkraft Sverige. NIR, pp 452-455

Bernitz U, Pehrson L, Rosen J, Sandgren C (2017) Immaterialrätt och konkurrens. Jure Förlag, Stockholm Borcher E, Bøggild F (2013) Markedsføringsloven, 3rd edn. Karnov Group, Copenhagen

Borcher E (2003) Produktefterligninger, 2nd edn. Thomson-GadJura, Copenhagen

Borcher E (2009) Produktefterligningsbeskyttelsen efter markedsføringslovens $\S 1$, U2009B.151. Ugeskrift for Retsvæsen, pp $151 \mathrm{ff}$

Brunsvig P (1960) Utilbörlig efterligning av produkt under den norske konkurranseloven. NIR, pp 146-165

Church O, Derclaye E, Stupfler G (2019) An empirical analysis of the design case law of the EU member states. IIC 50:685. https://doi-org.ezproxy.library.bi.no/10.1007/s40319-019-00813-0

Engelbrekt AB (2007) The Scandinavian model of unfair competition law. In: Hilty R, Henning-Bodewig F (eds) Law against unfair competition: towards a new paradigm in Europe, vol 1. MPI Studies on intellectual property, competition and tax law. Springer, Berlin, pp 161-181

Heide-Jørgensen C (2017) Lærebog i konkurrenceret, 3rd edn. Jurist- og økonomforbundets forlag, Copenhagen

Helset P, Reimers F, Stene T, Vik R (2009) Immaterialrett. Cappelen Damm, Oslo

Henning-Bodewig F (2006) Unfair competition law, European Union and member states. International competition law series. Kluwer Law, The Hague

Henning-Bodewig F (2013) (ed) International handbook on unfair competition. Beck Hart Nomos, Munich

Hilty R, Henning-Bodewig F (eds) (2007) Law against unfair competition: towards a new paradigm in Europe? Vol 1. MPI Studies on intellectual property, competition and tax law. Springer, Munich

Knoph R (1936) Åndsretten. Nationaltrykkeriet, Oslo

Koktvedgaard M (1965) Immaterialretspositioner. Jurist- og Økonomforbundets Forlag, Copenhagen

Kur A (2009) (No) freedom to copy? Protection of technical features under unfair competition law. In: Adelman MJ, Brauneis R, Drexl J, Nack R (eds) Patents and technological progress in a globalized world, vol 6. MPI Studies on intellectual property, competition and tax law. Springer, Berlin, pp 521-533

Lassen BS, Stenvik A (2006) Designrett. Cappelen Damm, Oslo

Levin M (1984) Formskydd: en rättsvetenskaplig studie av skyddet för estetiskt syftande industriell formgivning. LiberFörlag, Stockholm

Levin M (2017) Skyddet mot efterbildning - en europeisk smaksak numera. Amici curae Marknadsdomstolen 1971-2016. Jure Förlag, Stockholm, pp 283-300

Llewelyn D, Aplin T (2019) Intellectual property: patents, copyrights, trademarks \& allied rights. Classic Series. Sweet \& Maxwell

Lund A (2014) Høyesteretts dom om Tripp Trapp-stolen - et gjennomslag for Tharp? Vern for verket eller også for den kunstneriske idé som det uttrykker. NIR, pp 178-203 
Lunde T (2001) God forretningsskikk næringsdrivande imellom. Fagbokforlaget, Bergen

Lunde T, Michaelsen TL (2019) Markedsføringsloven med kommentarer. Gyldendal Akademisk, Oslo Løchen TC, Grimstad A (2003) Markedsføringsloven: kommentarutgave. Universitetsforlaget, Oslo

Madsen PB (2017) B2B and B2C marketing practices - the case for an integrated approach. In: Bernitz U, Heide-Jørgensen C (eds) Marketing and advertising law in a process of harmonization. Modern Studies in European Law, pp 171-185

Madsen B (2019) Markedsret, del 2, 7th edn. Jurist- og økonomforbundet, Copenhagen

Møgelvang-Hansen P, Riis T, Trzaskowski J (2017) Markedsføringsretten. Ex Tuto Publishing, Copenhagen

Nordell PJ (2005) Skyddet for funktionellt betingade utstyrslar. NIR, pp 433-463

Nordell PJ (2011) Transaktionstestet och dess tillämpning i Marknadsdomstolens praxis. NIR, pp $547-557$

Nordell PJ (2017) Unfair competition law: how can it work as an important complement to intellectual property protection. Are there missing links? In: Bernitz U, Heide-Jørgensen C (eds) Marketing and advertising law in a process of harmonization. Modern Studies in European Law, pp 222-232

Ohly A (2010) The freedom of imitation and its limits - a European perspective. IIC, pp 506-524

Ohly A (2018) "Buy me because I'm cool": the "marketing approach" and the overlap between design, trade mark and unfair competition law. In: Kur A, Levin M, Schovsbo JH (2018) (eds) The EU design approach, a global appraisal. Edward Elgar Publishing, Cheltenham, pp 108-141

Ringnes A (2016) Forholdet mellom immaterialrett og god forretningsskikk i etterligningssaker. In: Rettsavklaring og rettsutvikling. Festskrift til Tore Schei, pp 759-777

Rognstad O-A (2000) Om forholdet mellom retten til parallellimport og nasjonale regler om markedsføring. NIR, pp 320-336

Rognstad O-A (2012) Opphavsrett til brukskunst. Etterligning av TRIPP TRAPP-stolen. Varemerkerett. Rt. 2012, s. 1062 Nytt i privatretten No. 3, pp 19-21

Rognstad O-A (2019) Opphavsrett. Universitetsforlaget, Oslo

Rosenmeier M, Schovsbo JH (2015) Brugskunstbeskyttelsen mod «meget nærgående efterligninger» . Er Højesterets praksis på kant med EU-retten? U2015B.181, Ugeskrift for Retsvæsen, pp 181-185

Schovsbo JH (1996a) Grænsefladespørgsmål mellem immaterialretten og konkurrenceretten. Jurist- og $\emptyset$ konomforbundets Forlag, Copenhagen

Schovsbo JH (1996b) Passer til LEGO? U1996B.33, Ugeskrift for Retsvæsen, p 33 ff

Schovsbo JH, Svendsen NH (2002) Designret: designloven med kommentarer. Jurist- og Økonomforbundets Forlag, Copenhagen

Schovsbo JH (2011) Produktefterligninger: "Hvorfor Fanden" - dog ikke? In: Lego Andersen E et al (eds) S $\varnothing-$ og Handelsretten 150 år. Karnov, Copenhagen, pp 165-180

Schovsbo JH, Teilmann-Lock S (2016) We wanted more Arne Jacobsen chairs but all we got was boxes experiences from the protection of design in Scandinavia from 1970 til the Directive. IIC, pp 418-437. https://doi-org.ezproxy.library.bi.no/10.1007/s40319-016-0477-6

Sejersted F, Arnesen F, Rognstad OA, Kolstad O (2011) EØS-rett. Universitetsforlaget, Oslo

Stenvik A (2002) Rettsbeskyttelse av forretningskonsepter og-metoder. TfF, pp 482-522

Stenvik A (2006) Patentrett. Cappelen Damm, Oslo

Trzaskowski J (2017) Interpretation and assessment under the Unfair Commercial Practices Directive the ICC Code for advertising and marketing and the Commission's staff. In: Bernitz U, HeideJørgensen C (2017) (eds) Marketing and advertising law in a process of harmonization. Modern Studies in European Law, pp 85-103

Viken M (2012) Markedsundersøkelser som bevis i varemerke- og markedsføringsrett. Gyldendal Akademisk, Oslo

Viken M (2017) Bevisverdien av markedsundersøkelser - utviklingstendenser i Marknadsdomstolens praksis. Amici curiae Marknadsdomstolen 1971-2016. Jure Förlag, Stockholm, pp 635-648

Wold E (2010) Betydningen av subjektiv skyld i immaterial- og markedsføringsretten. Lov og Rett, pp $128-143$

Publisher's Note Springer Nature remains neutral with regard to jurisdictional claims in published maps and institutional affiliations. 